\title{
Industrial Automation Techniques based Internet of Things
}

\author{
P. Arumugam, T. Krishna Kumar
}

\begin{abstract}
Internet of Things (IoT) is the system of electronic devices implemented in the embedded platform that enables the program, sensors, and connection of networks for the collection and exchange of data and those led to the popularity of IoT. Here, we are building a network which monitors the industrial applications automatically and produce Alerts/Alarms and helps in making intelligent decisions with the help of IoT. Internet of things helps in developing effective industrial systems by making use of wireless devices,Android applications and sensors.
\end{abstract}

Key Words: IoT, Sensors, Embedded electronics.

\section{INTRODUCTION}

Internet of Things (IoT) is a technique that visualizes everything in this world as a part of internet and it covers large area and comprises of different objects like smart phones,digital cameras and sensors. When these devices are interconnected,it empowers more intelligent services which assist us in many needs.Different types of services are provided by these gigantic devices linked to internet and also yield large number of data and information. Cloud computing is an example of this modelthat enables access to a shared pool of configurable resources (computer, networks, servers, storage whenever required. This can be supplied as infrastructure, programs \& applications.Platforms based on cloud helps to connect and access anything when required in a ergonomical manner by useof customized portals and applications that are build in it. In short we can say that cloud behaves as a key to approach IoT. To interact with devices like sensors, we need large storage capacity,high computational power that empowers the data processing in real time and high speed system to get audio and video. Here we need to define the connection of Internet of Things and Cloud computing to address the large Data problems. We have also explained about Sensing as a service on cloud using few applications like Environment monitoring,etc. At last, we suggest a prototype model that provides sensing as a service on cloud. The Internet has an important part in our day-to-day life and coverage of network is increasing and the number of people using the network is also increased.Latest technology and techniques also affects the Internet. Now the importance is to the Internet of Things, the Internet of Services and cloud computing because it provides more real-time in turn.It provides the knowledge about location, climate, traffic,

Revised Manuscript Received on October 22, 2019.

* Correspondence Author

P. Arumugam, Research Scholar, Department of CSE, Bharath Institute of Higher Education and Research, Chennai, Tamilnadu, India.

Dr.T. Krishna Kumar, Professor, Department of CSE, Bharath Institute of Higher Education and Research, Chennai, Tamilnadu, India. local business and latest openings in service-oriented industry.IOT technologies has increased its importance in various industries.

\section{LITERATURE REVIEW}

At present its the era of automated systems.Internet has a great influence in our life as it lord to many new efficient technologies.Among them,the inclining technology is the 'Internet of Things'. An example is Home Automation System that make use of IoT to monitor and a control the electrical and electronic appliances at home from any place byuse of a Smartphone. Home automation system that is cost effective, reliable can be provided that helps in improving the use of wireless communication between user and the remote control.

This project concentrates on the management of home appliances even if the user is far away. The system is based on SMS and GSM that is used by the user. The GSM technology provides the system the opportunity to get accessed to the mechanism. 8051 Micro Controller is the major part of this project. The objective of this project is to explore a cost friendly resolution to enable the control of home appliances remotely. The motivation was to allow the users to automate their homesuniversally. The home appliances control system with an reasonable cost was to be built that should be mobile that provide remote access to the appliance[2].

Systems and procedures was provided that for the interaction with the users and for the transfer of data Moreover the updation of controller code and tag can be done automatically or semi automatically. A programmable logic controller (PLC) or programmable controller,digital computer that work as automation of electromechanical works which are used in industries and machines. The present disclosure relates facilitate the provision to industrial PCs. PLC is fabricated for many ingress and egress dispositions, enlarged temperature levels, electrical noise Immunity. Programs to manage machine work are mainly saved in battery-buffered or permanent memory[3].

\section{GOALS AND OBJECTIVES}

Developing a system which automatically monitors, alerts, take smart decisions and implement them in industrial applications using IoT.

\section{EXISTING SYSTEM}

In present scenario there are only methods to monitor

\section{Published By:}


uneven conditions but no way to alert them. Also the methods available now are time consuming.

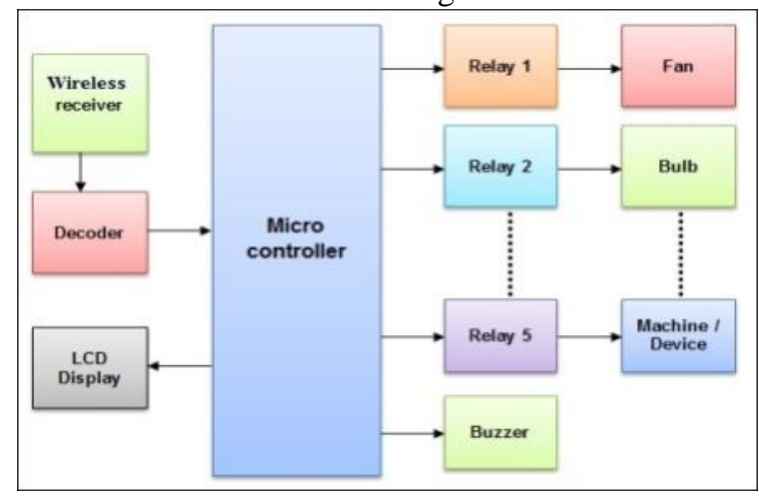

Fig. 1. Existing Block Diagram

\section{OVERVIEW OF SYSTEM}

In this era of automation and advanced computingusing IoT with Artificial Intelligence delivers promisingand effective solutions for the automation in Industry. To get the knowledge about the IoT developments in industries, this paper refers the present research of IoT, key enabling technologies, main IoT applications in industries, and challenges. The Internet of Sensors (Temperature sensor, Voltage sensor) senses the environment conditions and pass the Analog signal to the android devices. To each and every sensors present in Industrya threshold is set by the admin. Android helps the object in Sensing and managing remotely across the network infrastructure. This is illustrated in figure 2.

This resultant analog signal is compared with threshold and accordingly on or off the connected devices(light, fan, motor..).This is feasible through previous conditions in the database..

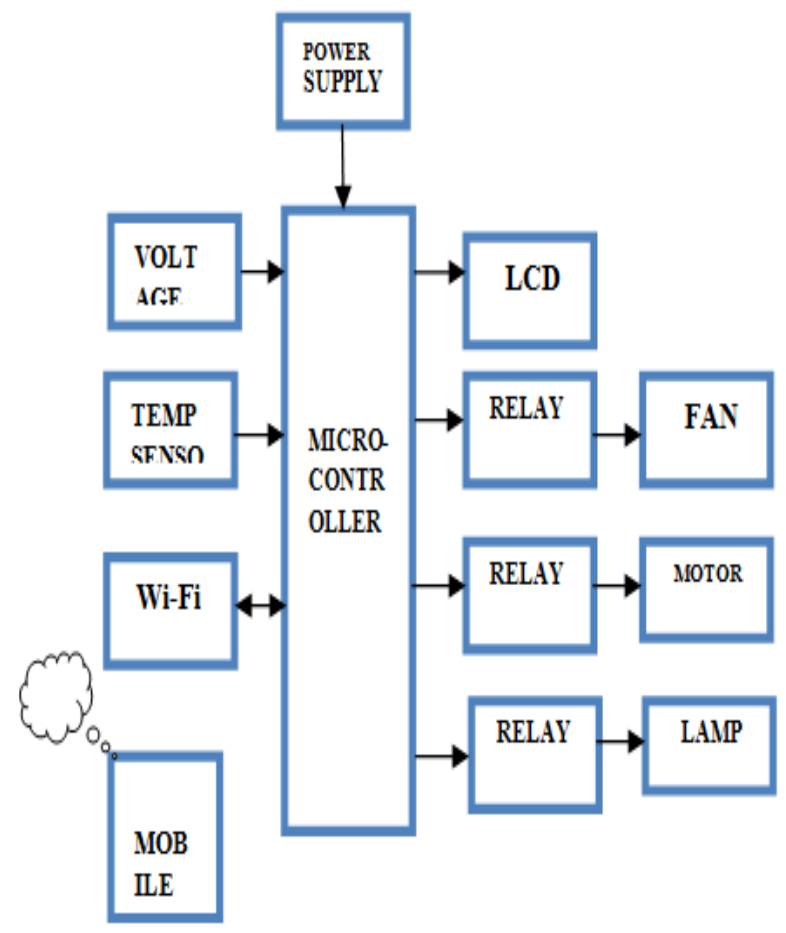

Fig. 2. Proposed Block Diagram

V. RESULT

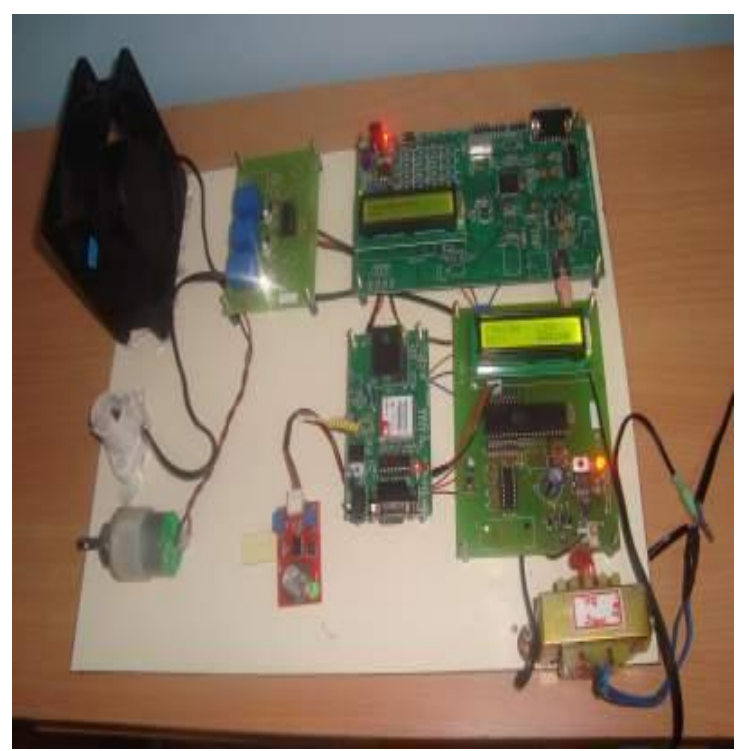

It consist of two units one is control unit, it includes main processing unit connected with microcontroller and two electrical devices connected with controller like machines, motor. And another unit is mobile. Both the units are communicated via internet. If we control the device using mobile through android app. In this app we create the gadgets as per our requirements like temperature monitoring or load control using with push buttons or switches. All the process is processing through cloud server.

\section{APPLICATIONS}

Industry and office:-Control and Monitor circumstances by implementing sensors over the machines by using IoT.

Hospital and Labs: -Doctor can check the patients present statusin his android phone byplacing a sensor on patient's body and this also helps in making mandatory actions and decisions.

Home:-It helps to monitor and control household appliances using sensors.

\section{CONCLUSION}

In Earlier times we couldonly find out the conditions with the use of cameras. Internet of Things (IoT) are implemented in industries to reduce manual overhead,to find out as well as to alert the people to take necessary measures,but still our requirements are not completely fulfilled.As this process is time consuming and even will harm life as well as property.Thus we go for a system for Industrial Automation using IoT.

\section{REFERENCES}

1. Kumaravel A., Meetei O.N.,An application of non-uniform cellular automata for efficient cryptography,2013 IEEE Conference on Information and Communication Technologies, ICT 2013,V-,I-,PP-1200-1205,Y-2013

2. Kumarave A., Rangarajan K.,Routing alogrithm over semi-regular tessellations,2013 IEEE Conference on Information and Communication Technologies, ICT 2013,V-,I-,PP-1180-1184,Y-2013

3. Dutta P., Kumaravel A.,A novel approach to trust based identification of leaders in social networks,Indian Journal of Science and Technology,V-9,I-10,PP--,Y-2016

4. Kumaravel A., Dutta P.,Application of Pca for context selection for collaborative filtering,Middle - East Journal of Scientific 
Research,V-20,I-1,PP-88-93,Y-2014

5. Kumaravel A., Rangarajan K.,Constructing an automaton for exploring dynamic labyrinths,2012 International Conference on Radar, Communication and Computing, ICRCC 2012,V-,I-,PP-161-165,Y-2012

6. Kumaravel A.,Comparison of two multi-classification approaches for detecting network attacks, World Applied Sciences Journal,V-27,I-11,PP-1461-1465,Y-2013

7. Tariq J., Kumaravel A.,Construction of cellular automata over hexagonal and triangular tessellations for path planning of multi-robots,2016 IEEE International Conference on Computational Intelligence and Computing Research, ICCIC 2016,V-,I-,PP--,Y-2017

8. Sudha M., Kumaravel A.,Analysis and measurement of wave guides using poisson method,Indonesian Journal of Electrical Engineering and Computer Science,V-8,I-2,PP-546-548,Y-2017

9. Ayyappan G., Nalini C., Kumaravel A.,Various approaches of knowledge transfer in academic social network,International Journal of Engineering and Technology,V-,I-,PP-2791-2794,Y-2017

10. Kaliyamurthie, K.P., Sivaraman, K., Ramesh, S. Imposing patient data privacy in wireless medical sensor networks through homomorphic cryptosystems 2016, Journal of Chemical and Pharmaceutical Sciences .

11. Kaliyamurthie, K.P., Balasubramanian, P.C.An approach to multi secure to historical malformed documents using integer ripple transfiguration 2016 Journal of Chemical and Pharmaceutical Sciences 9

12. A.Sangeetha,C.Nalini,"Semantic Ranking based on keywords extractions in the web", International Journal of Engineering \& Technology, 7 (2.6) (2018) 290-292

13. S.V.GayathiriDevi,C.Nalini,N.Kumar,"An efficient software verification using multi-layered software verification tool "International Journal of Engineering \& Technology, 7(2.21)2018 454-457

14. C.Nalini,ShwtambariKharabe,"A Comparative Study On Different Techniques Used For Finger - Vein Authentication”, International Journal Of Pure And Applied Mathematics, Volume 116 No. 8 2017, 327-333, Issn: 1314-3395

15. M.S. Vivekanandan and Dr. C. Rajabhushanam, "Enabling Privacy Protection and Content Assurance in Geo-Social Networks", International Journal of Innovative Research in Management, Engineering and Technology, Vol 3, Issue 4, pp. 49-55, April 2018.

16. Dr. C. Rajabhushanam, V. Karthik, and G. Vivek, "Elasticity in Cloud Computing", International Journal of Innovative Research in Management, Engineering and Technology, Vol 3, Issue 4, pp. 104-111, April 2018.

17. K. Rangaswamy and Dr. C. Rajabhushanamc, "CCN-Based Congestion Control Mechanism In Dynamic Networks", International Journal of Innovative Research in Management, Engineering and Technology, Vol 3, Issue 4, pp. 117-119, April 2018.

18. Kavitha, R., Nedunchelian, R., "Domain-specific Search engine optimization using healthcare ontology and a neural network backpropagation approach", 2017, Research Journal of Biotechnology, Special Issue 2:157-166

19. Kavitha, G., Kavitha, R., "An analysis to improve throughput of high-power hubs in mobile ad hoc network" ,2016, Journal of Chemical and Pharmaceutical Sciences, Vol-9, Issue-2: 361-363

20. Kavitha, G., Kavitha, R., "Dipping interference to supplement throughput in MANET" , 2016, Journal of Chemical and Pharmaceutical Sciences, Vol-9, Issue-2: 357-360

21. Michael, G., Chandrasekar, A.,'Leader election based malicious detection and response system in MANET using mechanism design approach", Journal of Chemical and Pharmaceutical Sciences(JCPS) Volume 9 Issue 2, April - June 2016.

22. Michael, G., Chandrasekar, A.,'Modeling of detection of camouflaging worm using epidemic dynamic model and power spectral density", Journal of Chemical and Pharmaceutical Sciences(JCPS) Volume 9 Issue 2, April - June 2016.

23. Pothumani, S., Sriram, M., Sridhar, J., Arul Selvan, G., Secure mobile agents communication on intranet,Journal of Chemical and Pharmaceutical Sciences, volume 9, Issue 3, Pg No S32-S35, 2016

24. Pothumani, S., Sriram, M., Sridhar, Various schemes for database encryption-a survey, Journal of Chemical and Pharmaceutical Sciences, volume 9, Issue 3, Pg NoS103-S106, 2016

25. Pothumani, S., Sriram, M., Sridhar, A novel economic framework for cloud and grid computing, Journal of Chemical and Pharmaceutical Sciences, volume 9, Issue 3, Pg No S29-S31, 2016

26. Priya, N., Sridhar, J., Sriram, M. "Ecommerce Transaction Security Challenges and Prevention Methods- New Approach" 2016,Journal of Chemical and Pharmaceutical Sciences, JCPS Volume 9 Issue 3.page no:S66-S68

27. Priya, N.,Sridhar,J.,Sriram, M."Vehicular cloud computing security issues and solutions" Journal of Chemical and Pharmaceutical Sciences(JCPS) Volume 9 Issue 2, April - June 2016

28. Priya, N., Sridhar, J., Sriram, M. "Mobile large data storage security in cloud computing environment-a new approach" JCPS Volume 9 Issue 2. April - June 2016

29. Anuradha.C, Khanna.V, "Improving network performance and security in WSN using decentralized hypothesis testing "Journal of Chemical and Pharmaceutical Sciences(JCPS) Volume 9 Issue 2, April - June 2016

\section{AUTHORS PROFILE}

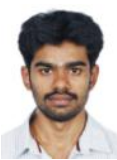

P. Arumugam, Research Scholar, Department of CSE Bharath Institute of Higher Education and Research, Chennai, Tamilnadu, India.

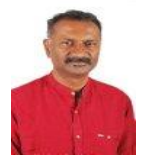

Dr.T. Krishna Kumar, Professor, Department of CSE, Bharath Institute of Higher Education and Research, Chennai, Tamilnadu, India. 